The Free Internet Journal

for Organic Chemistry
Paper

Arkivoc 2017, part iii, 41-54

\title{
Cerium(IV) ammonium nitrate for the tandem nitration and oxidative rearrangement of 2-acetyl-1-naphthol benzoylhydrazones into 1,2-diacylnaphthalenes; synthesis of benzo[f]phthalazines
}

\author{
Alexandra Tzinavou, ${ }^{a}$ Chrysanthi Dolka, ${ }^{a}$ Petros G. Tsoungas, ${ }^{b}$ Erik Van der Eycken, ${ }^{c}$ \\ Luc Van Meervelt, ${ }^{d}$ and George Varvounis ${ }^{a *}$
}

a Section of Organic Chemistry and Biochemistry, Department of Chemistry, University of loannina, 45110 loannina, Greece

${ }^{b}$ Department of Biochemistry, Hellenic Pasteur Institute, 127 Vas. Sofias Ave., 11521 Athens, Greece

c Laboratory for Organic \& Microwave-Assisted Chemistry (LOMAC), Department of Chemistry Katholieke Universiteit Leuven, Celestijnenlaan 200F, B-3001 Leuven, Belgium and Peoples Friendship

University of Russia (RUDN University) 6 Miklukho-Maklaya Street, Moscow, 117198, Russia

${ }^{d}$ Biomolecular Architecture, Department of Chemistry, Katholieke Universiteit Leuven

Celestijnenlaan 200F, B-3001, Leuven, Belgium

Email: gvarvoun@cc.uoi.gr

\section{Dedicated to Prof. Oleg A. Rakitin on the occasion of his $65^{\text {th }}$ birthday}

Received 01-09-2017

Accepted 02-08-2017

Published on line 03-24-2017

\section{Abstract}

A novel nitration and oxidation reaction sequence of 2-acetyl-1-naphthol benzoylhydrazones with CAN is presented. There is strong indication that nitration precedes an oxidative rearrangement to 1,2-diacyl-4nitronaphthalenes or oxidative electrocyclisation to 3-methyl-5-nitronaphtho[2,1- $d$ ] isoxazole. Condensation of 1,2-diacyl-4-nitronaphthalenes with hydrazine hydrate yields 1,4-disubstituted benzo[f]phthalazines.<smiles>[R]C(=O)N/N=C(\C)c1ccc2ccccc2c1O</smiles><smiles>Cc1noc2c1cc([N+](=O)[O-])c1ccccc12</smiles><smiles>[R]C(=O)c1c(C(C)=O)cc([N+](=O)[O-])c2ccccc12</smiles><smiles>[R]C(=O)c1c(C(C)=O)cc([N+](=O)[O-])c2ccccc12</smiles>

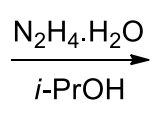<smiles>[R]c1nnc(C)c2cc([N+](=O)[O-])c3ccccc3c12</smiles>

Keywords: Cerium(IV) ammonium nitrate, benzoylhydrazones, nitration, oxidative rearrangement, electrocyclisation, benzo[f]phthalazines 


\section{Introduction}

Cerium(IV) ammonium nitrate (CAN) has received considerable attention as a powerful one-electron oxidant with many uses in organic synthesis. Its extensive use has been dictated by its high reduction potential (1.61 $\mathrm{eV}),+3$ and +4 oxidation states of cerium, low cost, stability in air, easy and simple handling, low toxicity, solubility in many organic solvents and a versatile reactivity profile. Reactions of CAN include, oxidation, oxidative addition, oxidative catalysis, nitration, photo-oxidation, carbon-carbon and carbon-heteroatom bond formation, carbon-carbon, carbon-heteroatom and Si-O bond cleavage, fragmentation, alkoxylation, esterification and transesterification, dehydrogenation, catalysis of multicomponent syntheses and polymer grafting, as described in recent review articles. ${ }^{1,2}$ CAN has played a significant role in oxidative cyclisations giving access to various heterocycles, although the synthesis of five-membered rings with two heteroatoms is limited to benzimidazoles, ${ }^{3}$ pyrazoles, ${ }^{4}$ benzothiazoles ${ }^{5,6}$ and isoxazoles. ${ }^{7}$ CAN has been reported to cleave semicarbazones to the corresponding aldehydes and ketones ${ }^{8}$ but hydrazones are not affected. Furthermore, the reagent has not been used on 2-hydroxyaryl ketone acylhydrazones. A transformation of the latter to 1,2diacylbenzenes was first reported by Kotali and Tsoungas ${ }^{9,10}$ using lead tetraacetate (LTA) and its mechanism was studied by Katritzky et al. ${ }^{11}$ The use of iodobenzene diacetate (IBD), ${ }^{12}$ polystyrene-supported IBD ${ }^{13}$ or cross-linked poly[styrene(iodoso diacetate) $]^{14}$ as oxidants in this transformation, gives comparable results. Other methods of synthesizing 1,2-diacylbenzenes are: palladium(II)-catalyzed direct acylation of acetophenone $\mathrm{N}$-Boc hydrazones with aldehydes via $\mathrm{C}-\mathrm{H}$ bond activation ${ }^{15}$ and $\mathrm{Pd}$-catalysed oxidative $\mathrm{C}-\mathrm{H}$ bond coupling of acetophenone $O$-methyl oximes and aldehydes to give 1,2-diacylbenzene $O$-methyl oximes which are then hydrolysed, ${ }^{16}$ oxidation of benzhydrols with selenium dioxide, ${ }^{17}$ of benzofurans with LTA, $^{18}$ and of 2-ethylacetophenone with potassium permanganate, ${ }^{19}$ or acylating benzene with 2 -acetylbenzoyl chloride. ${ }^{20}$ It is worth noting that 2,3-diacylnaphthalenes are known, ${ }^{21}$ while their 1,2 -diacyl regioisomers are hitherto unreported.

The phthalazine ring system is the core unit in many biologically active compounds. ${ }^{22-24}$ Despite the large number of phthalazine derivatives already prepared and biologically evaluated, the importance of this structure in biomedical applications poses a need for greater diversity and thus a synthesis challenge. On this line, benzo fused phthalazines, such as benzo[f]phthalazines, which have been sparsely explored, could prove a valuable contribution. The first benzo[f]phthalazine to be reported was the parent compound, obtained both by heating bis-(1-naphthylmethylene)hydrazine in PPA $^{25}$ or by irradiating 4-[(Z)-2-phenylvinyl]pyridazine in sulfuric acid. ${ }^{26}$ There are only a few aromatic 1,4-disubstituted benzo[f]phthalazines that have been synthesized by ring closure of appropriate precursors. Inverse electron demand aza-Diels-Alder reaction of 3,6-bis(trifluoromethyl)-1,2,4,5-tetrazine with naphthalene, followed by extrusion of nitrogen and oxidation, leads to 1,4-bis(trifluoromethyl)benzo[f]phthalazine. ${ }^{27}$ By using 3,6-dimethyl-(or diphenyl)-1,2,4,5-tetrazine or dimethyl 1,2,4,5-tetrazine-3,6-dicarboxylate as the diene and 1-(6-methoxy-3,4-dihydronaphthalen-2-yl)pyrrolidine as the dienophile, the corresponding 1,4-disubstituted benzo[f]phthalazines have also been prepared. ${ }^{28}$ Cycloaddition reactions between dimethyl 1,2,4,5-tetrazine-3,6-dicarboxylate and naphthalene or 1-methoxynaphthalene work equally well. ${ }^{29}$ Intramolecular acyl substitution of the appropriate 2-(5methylpyridazin-4-yl)benzamide, in the presence of LDA, provides 4-chloro-9-fluoro-1-methoxybenzo[f]phthalazin-6-ol. ${ }^{30}$ Intramolecular condensation of 2-(2-benzyl-5-methyl-3-oxo-2,3-dihydropyridazin-4yl)benzaldehyde with $\mathrm{Cs}_{2} \mathrm{CO}_{3}$, under microwave irradiation at $130{ }^{\circ} \mathrm{C}$, produces 3-benzylbenzo[f]phthalazin4(3H)-one. ${ }^{31}$ 2,3-Dihydrobenzo[f]phthalazine-1,4-diones are synthesized by heating, dimethyl naphthalene1,2-dicarboxylates with hydrazine hydrate in alcohols $\mathrm{s}^{32,33}$ and 1,2-naphthalenedicarboxylic anhydride with hydrazine hydrate in glacial acetic acid. ${ }^{31}$

Of the numerous articles on the synthesis, reactivity and bioactivity of isoxazoles and their arene-fused derivatives, the following have been gleaned to stress their significance. ${ }^{34-40}$ It is of particular note that the ring is commonly built-up, either intra- or intermolecularly, through the engagement of an oxime entity, 
donating to the ring $\mathrm{N}-\mathrm{O}$ bond. CAN-mediated transformation of acetone and acetophenone into nitrile oxides, followed by 1,3-dipolar cycloaddition with alkenes and alkynes, is a useful one-pot synthesis of 3acetyl- and 3-benzoylisoxazole derivatives. ${ }^{7}$ However, there have been no reports of isoxazole formation from a hydrazone precursor and CAN.

Hydrazone functional groups endow molecules with unique physical and chemical properties. Their nitrogen atoms are nucleophilic while the imine carbon centre has a dual electrophilic and nucleophilic character. ${ }^{41}$ Aspects of their structure and reactivity have been reviewed. ${ }^{42}$ There are no reports on 2-acetyl-1naphthol benzoylhydrazones other than those presented in this study. However, 1-naphthaldehyde benzoylhydrazones are known in the literature. There are examples of their effectiveness against a variety of drug resistant HIV-1 RT mutants ${ }^{43}$ and their use as parasitic protease inhibitors. ${ }^{44}$ Due to their chelation with a variety of metal ions, ${ }^{45}$ spectrophotometric methods have been developed for the determination of several of these metal ions in solution. ${ }^{46}$ In one report, their chelation with iron formed complexes were found to possess antimalarial activity. ${ }^{47}$

\section{Results and Discussion}

Herein, we describe the unprecedented reaction of 2-acetyl-1-naphthol benzoylhydrazones 3a-e with CAN (Scheme 1). The reaction of 3a-e with 1 equivalent of CAN produced three products, 2-acetyl-4-nitro-1naphthol benzoylhydrazones $\mathbf{4 a - e , ~ 1 , 2 - d i a c y l - 4 - n i t r o n a p h t h a l e n e s ~ 5 a - d ~ a n d ~ 3 - m e t h y l - 5 - n i t r o n a p h t h o [ 2 , 1 - d ] - ~}$ isoxazole (6). Starting materials 3a-e were prepared in good yields (70-85\%) by the reaction of 2-acetyl-1naphthol (1) with the corresponding hydrazides $\mathbf{2 a - e}$, in refluxing propan-2-ol, containing glacial acetic acid as catalyst. Hydrazones $\mathbf{3 a - e}$, in acetonitrile, were subjected to a slight excess of CAN for 1 hour at ambient temperature. In all reactions, TLC examination confirmed complete conversion of starting material into three products. One of the products precipitated out of the reaction mixture, collected at $0{ }^{\circ} \mathrm{C}$, crystallised from either acetonitrile or a mixture of DMSO and water in moderate yields (47-52\%) and identified as 4nitrobenzoylhydrazones $4 a-e$. Column chromatography allowed the isolation of the remaining two products. The less polar compound, obtained in low yield (15-30\%), was the same product in all reactions. It was crystallized from a mixture of dichloromethane and hexane and identified as the fused isoxazole 6 . The more polar compound, also crystallized from a mixture of dichloromethane and hexane, was isolated in slightly better yields (28-32\%) and was identified as the 1,2-diacylnaphthalene 5a-d, Table 1. Derivative 5e was not isolated possibly because intermediate III $\mathrm{R}=\mathrm{Me}$ (Scheme 2 ) lacking an aryl group is not stable enough to be formed. Nevertheless, 4 e was obtained in 50\% yield and the corresponding 6 in 30\% yield.

Unambiguous confirmation of the structure of compounds $\mathbf{5 a}$ and $\mathbf{6}$ was obtained from their single crystal $\mathrm{X}$-ray analysis, shown in Figs 1 and 2 (and see the Supporting Information). The ${ }^{1} \mathrm{H}$ NMR spectra of 4a-e show the broad singlets of the $\mathrm{OH}$ protons, unexpectedly shifted to $16.32-16.64 \mathrm{ppm}$, the NH protons as broad singlets at $11.35-12.03 \mathrm{ppm}$ and the $\mathrm{H}-3$ protons as sharp singlets at $8.65-8.73 \mathrm{ppm}$. The benzoyl carbonyl 


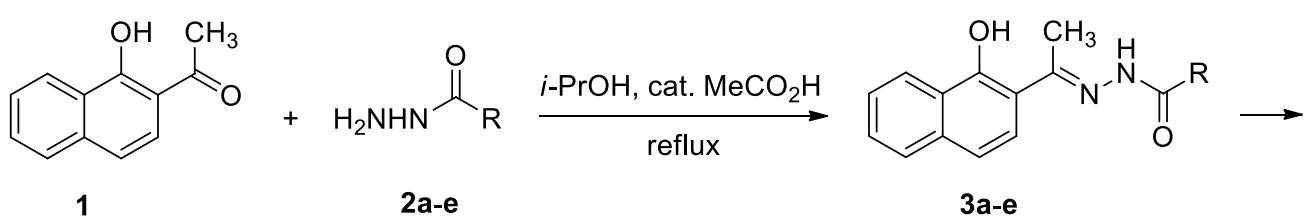<smiles>[R]C(=O)c1c(C(C)=O)cc([N+](=O)[O-])c2ccccc12</smiles>

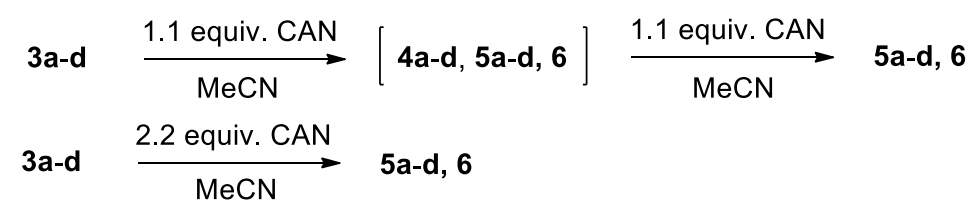

a: $\mathrm{R}=\mathrm{Ph}, \mathbf{b}: \mathrm{R}=4-\mathrm{MeC}_{6} \mathrm{H}_{4}, \mathbf{c}: \mathrm{R}=4-\mathrm{MeOC}_{6} \mathrm{H}_{4}, \mathbf{d}: \mathrm{R}=4-\mathrm{O}_{2} \mathrm{NC}_{6} \mathrm{H}_{4}, \mathbf{e}: \mathrm{R}=\mathrm{Me}$ Yields: 3a $82 \%$, 3b $73 \%$, 3c $75 \%$, 3d $70 \%$, 3e $60 \%$

Scheme 1. Preparation of 3a-e and reaction with CAN.

resonances of $\mathbf{5 a - d}$ are the most downfield shifted peaks of the ${ }^{13} \mathrm{C}$ NMR spectra, appearing at 195.80-196.93 ppm whereas the acetyl carbonyls are found at 195.07-195.69 ppm. In the ${ }^{1} \mathrm{H}$ NMR spectrum of 6 the singlet at $8.47 \mathrm{ppm}$ corresponds to $\mathrm{H}-4$, uncoupled as expected.

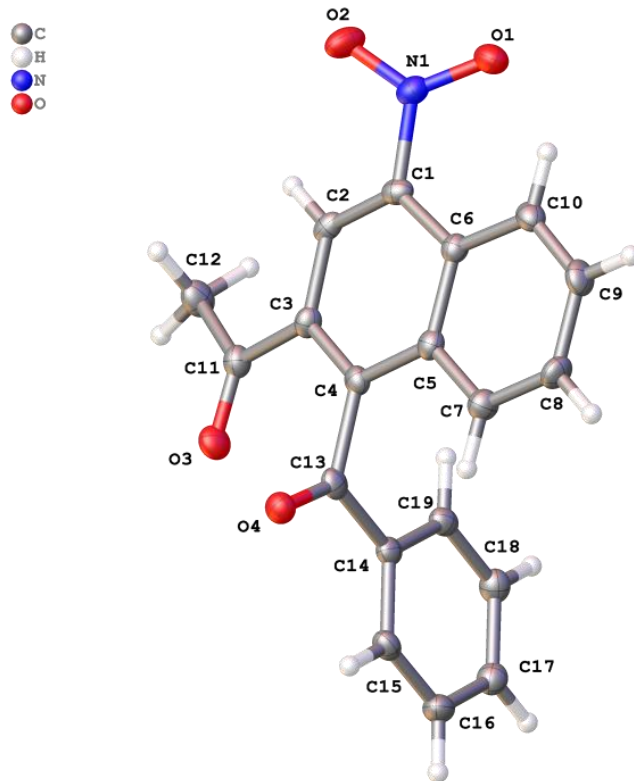

Figure 1. Molecular structure of $\mathbf{5 a}$ showing displacement ellipsoids drawn at the $50 \%$ probability level. Only one of the two molecules in the asymmetric unit is shown.

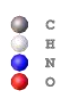

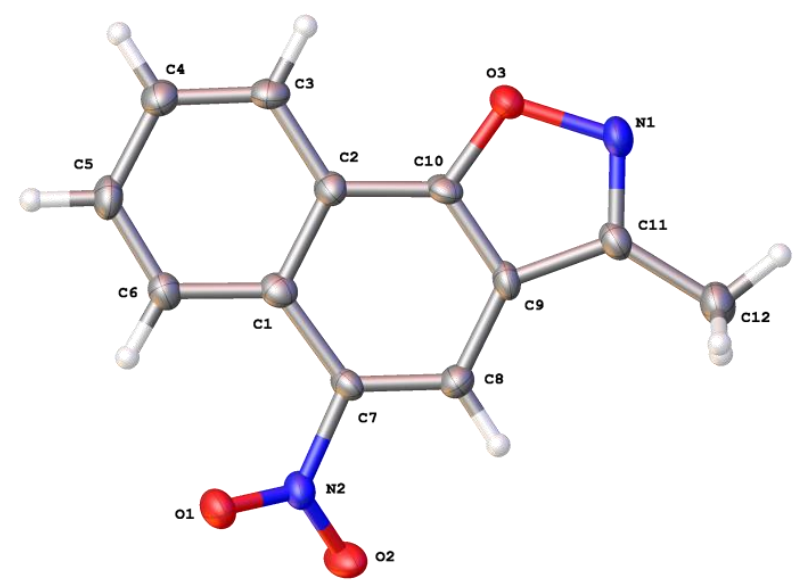

Figure 2. Molecular structure of 6 showing displacement ellipsoids drawn at the $50 \%$ probability level.

At this point, the question arose whether $\mathbf{4}$ is a precursor of $\mathbf{5}$ and $\mathbf{6}$. To that end, the reaction of $\mathbf{3 a - d}$ with one equivalent of CAN was repeated and after one hour having established the presence of $4 \mathbf{a}-\mathbf{d}, \mathbf{5 a - d}$ 
and 6 in the reaction mixture by TLC examination, 1 more equivalent of CAN was added that resulted in the isolation of only $\mathbf{5 a - d}$ and $\mathbf{6}$ (Table 2). The reaction was also tested by using a two-fold excess of CAN on $\mathbf{3 a - d}$ from the start of the reaction, which provided $\mathbf{5 a - d}$ and $\mathbf{6}$ directly (Table 3). These experiments therefore confirm that the reaction indeed proceeds via an initial nitration of $\mathbf{3} \mathbf{a}-\mathbf{d}$ to $\mathbf{4 a}-\mathbf{d}$, followed by oxidative transformation of the isolable intermediates $\mathbf{4 a - d}$ into $\mathbf{5 a}-\mathbf{d}$ and $\mathbf{6}$. The yields of $\mathbf{5 a - d}$ and $\mathbf{6}$ by the two-step method are slightly higher than those obtained by the direct method (Tables 2 and 3) while the yields of compounds $5 \mathbf{a}-\mathbf{d}$, useful as doubly electrophilic precursors, are reasonably good, $63-68 \%$ by the two-step method and $60-64 \%$ by the direct method.

Table 1. Reaction of 3 with 1 equiv. of CAN to give 4,5 and 6 , via Scheme 1

\begin{tabular}{cccccccc}
\hline Entry & Starting material & Product & Yield\% $^{a}$ & Product & Yield\% & Product & Yield $\%^{a}$ \\
\hline 1 & 3a & 4a & 47 & $\mathbf{5 a}$ & 32 & $\mathbf{6}$ & 18 \\
2 & 3b & 4b & 50 & $\mathbf{5 b}$ & 28 & $\mathbf{6}$ & 19 \\
3 & 3c & 4c & 48 & $\mathbf{5 c}$ & 30 & $\mathbf{6}$ & 20 \\
4 & 3d & 4d & 52 & $\mathbf{5 d}$ & 30 & $\mathbf{6}$ & 15 \\
5 & $\mathbf{3 e}$ & $\mathbf{4 e}$ & 50 & $\mathbf{5 e}$ & - & $\mathbf{6}$ & 30 \\
\hline
\end{tabular}

a After column chromatography

Table 2. Reaction of $\mathbf{3}$ with 1 equiv. of CAN followed by addition of another 1 equiv. of CAN to give $\mathbf{5}$ and $\mathbf{6}$, via Scheme 1

\begin{tabular}{cccccc}
\hline Entry & Starting material & Product & Yield\% $^{\mathrm{a}}$ & Product & Yield\% ${ }^{\mathrm{a}}$ \\
\hline 1 & 3a & $\mathbf{5 a}$ & 65 & $\mathbf{6}$ & 26 \\
2 & 3b & $\mathbf{5 b}$ & 63 & $\mathbf{6}$ & 28 \\
3 & 3c & $\mathbf{5 c}$ & 64 & $\mathbf{6}$ & 30 \\
4 & 3d & $\mathbf{5 d}$ & 68 & $\mathbf{6}$ & 24 \\
\hline \multicolumn{2}{r}{ After column chromatography }
\end{tabular}

Table 3. Reaction of $\mathbf{3}$ with 2 equiv. of CAN to give 5 and $\mathbf{6}$, via Scheme 1

\begin{tabular}{cccccc}
\hline Entry & Starting material & Product & Yield\% $^{\text {a }}$ & Product & Yield\% $^{\text {a }}$ \\
\hline 1 & 3a & 5a & 62 & $\mathbf{6}$ & 25 \\
2 & 3b & 5b & 60 & $\mathbf{6}$ & 27 \\
3 & 3c & 5c & 61 & $\mathbf{6}$ & 29 \\
4 & 3d & 5d & 64 & $\mathbf{6}$ & 23 \\
\hline \multicolumn{2}{r}{ After column chromatography }
\end{tabular}

The formation of the isolated products can be rationalized as follows (Scheme 2). Key intermediate 4 is initially formed by an electrophilic aromatic substitution reaction on $\mathbf{3}$ by CAN, acting as a nitronium carrier, by analogy to a report on $\mathrm{N}, \mathrm{N}$-dialkylanilines. ${ }^{48}$ Thus, the first step is probably the addition of the activated $\mathrm{C}-4$ of 3 onto the $\mathrm{N}=\mathrm{O}$ group of $\mathrm{CAN}$ to form an intermediate species I, from which elimination of $\mathrm{Ce}(\mathrm{OH})\left(\mathrm{NO}_{3}\right)_{5} 5^{2-}$ and re-aromatization leads to 4 . The following steps of the mechanism are analogous to the oxidative transformation of 2-hydroxy aryl ketone acylhydrazones into 1,2-diacylbenzenes by $\mathrm{Pb}(\mathrm{OAc})_{4}$, studied by Katritzky et al. ${ }^{11}$ An oxidative cyclisation of aromatic aldehyde acylhydrazones to unsymmetrically 2,5disubstituted 1,3,4-oxadiazoles, ${ }^{49}$ by CAN, lends further support to our proposed pathway. Therefore, we 
propose that CAN initiates free radical oxidation of $\mathbf{4}$ to give an intermediate $\beta$-azo-o-quinone methide II, which undergoes intramolecular cyclisation to form the 1,3,4-oxadiazoline intermediate III. In intermediate III the naphthoxide oxygen atom adds to the carbocation of the oxadiazoline ring to form the tetracyclic epoxynaphthoxadiazepine species IV. Elimination of nitrogen from IV leads to the formation of unstable naphthoxirenofuran $\mathbf{V}$, which undergoes electrocyclic rearrangement to form $\mathbf{5}$.

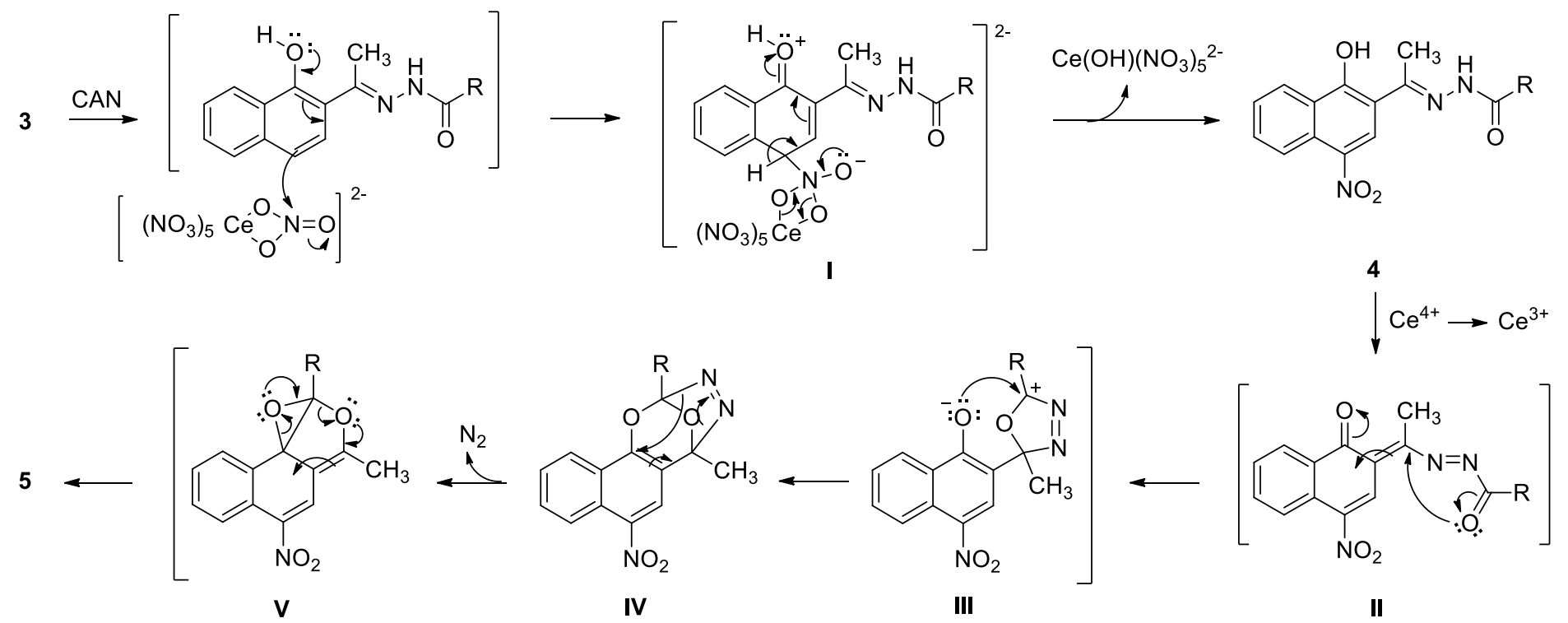

Scheme 2. Plausible mechanism for the formation of $\mathbf{4}$ and $\mathbf{5}$ from $\mathbf{3}$.

The formation of $\mathbf{6}$ dictates that a competing free radical oxidation of $\mathbf{4}$ seems to be running in parallel (Scheme 3). This is rationalised as follows. In the $\mathrm{H}$-bonded "locked" conformation shown, 4 is oxidised to $\beta$ azo-o-quinone methide II followed by its electrocyclisation to isoxazole- $\mathrm{N}$-acylimide VI. It is reasonable to assume that the next step, under the pertaining reaction conditions, is a $\mathrm{N}-\mathrm{N}$ bond cleavage in $\mathbf{V I}$ to give 6 . The released benzoyl nitrene species then rapidly undergoes the Curtius rearrangement to produce an aryl isocyanate.

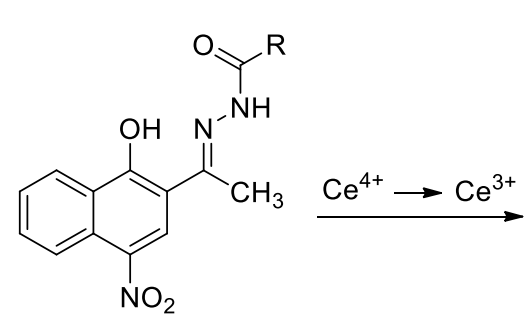

4

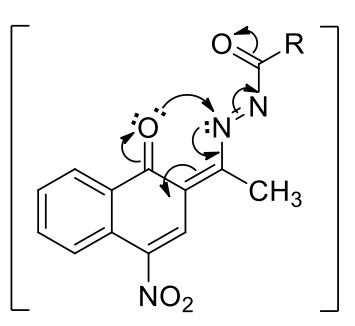

II'

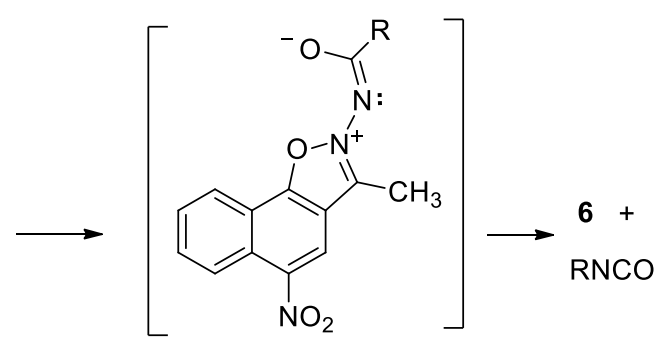

VI

Scheme 3. Plausible mechanism for the formation of 6 from 4.

A common feature in both oxidation pathways (Schemes 2 and 3 ) is the intermediacy of transient $\beta$-azo- 0 quinone methide ' II' that adopts a conformation dependent on the orientation taken up by the benzoylhydrazone substituent in 4 . In these reactions, strong electron withdrawing $p-\mathrm{NO}_{2}$ substitution in 4 is expected to reduce its susceptibility to further oxidation pathways and thus increase the likelihood of alternative competing reactions. This, perhaps, can serve as a rationale for both isolated $\mathbf{5}$ and $\mathbf{6}$. Furthermore, the "locked" orientation adopted by 4 tends to be favoured by the intramolecular $\mathrm{O}-\mathrm{H}$... $\mathrm{N}$ hydrogen bonding 
between the phenol and imine sites. Its resonance-assisted stabilisation, ${ }^{50}$ however, is rather diminished by the effect of the $p-\mathrm{NO}_{2}$ substituent and therefore may explain the lead of $\mathbf{5}$ over $\mathbf{6}$.

1,2-Diacylnaphthalenes $5 \mathbf{a}-\mathbf{d}$, upon reaction with 1 equivalent of hydrazine hydrate in propan-2-ol, at room temperature for 1 hour, via consecutive intermolecular condensation and cyclodehydration reactions, led, after crystallization from propan-2-ol, to the corresponding 1,4-disubstituted benzo[f]phthalazines 7a-d, in excellent yields (89-98\%) (Scheme 4). The most downfield signal in the ${ }^{1} \mathrm{H}$ NMR spectra of $7 \mathrm{a}-\mathbf{d}$ is the singlet of $\mathrm{H}-5$, adjacent to the nitro group, at 8.52-8.57 ppm. In the ${ }^{13} \mathrm{C}$ NMR spectra of these compounds the peaks of $\mathrm{C}-1$, bonded to the aryl group, are at 155.13-157.16 ppm while those of $\mathrm{C}-4$, bonded to the methyl group, are at 156.99-160.64 ppm.
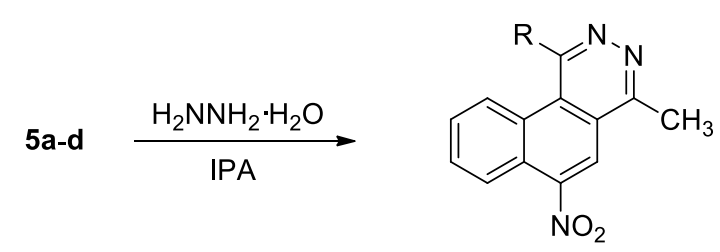

$7 \mathbf{a}(89 \%), 7 \mathbf{b}(98 \%)$

7c $(98 \%), 7 d(94 \%)$

Scheme 4. Preparation of 7a-d from 5a-d with hydrazine hydrate.

The synthesis of phthalazines $\mathbf{7}$, besides serving as a further confirmation to the structure of $\mathbf{5}$, is a useful contribution to existing synthetic routes towards this important heterocycle.

\section{Conclusions}

In conclusion, an unprecedented nitration-oxidation tandem reaction of 2-acetyl-1-naphthol benzoylhydrazones with CAN has been described. The reaction proceeds via a $\beta$-azo-o-quinone methide intermediate which, depending on its conformation, undergoes a rearrangement to afford 1,2-diacyl-4-nitronaphthalenes and an electrocyclisation to give 3-methyl-5-nitronaphtho[2,1- $d$ ] isoxazole. The 1,2-diacyl-4-nitronaphthalenes, condensed with hydrazine hydrate, offer a useful route to 1,4-disubstituted benzo[f]phthalazines.

\section{Experimental Section}

General. All reactions were carried out under a $\mathrm{N}_{2}$ atmosphere. Solvents and reagents were used as received from the manufacturers (Aldrich, Acros, Fluka, and Alfa Aesar) except for THF, DCM, MeOH, EtOAc, hexane and toluene that were purified and dried according to recommended procedures. Organic solutions were concentrated by rotary evaporation at $23-40{ }^{\circ} \mathrm{C}$ under 15 Torr. Melting points were taken on a Büchi 510 apparatus. ${ }^{1} \mathrm{H}$ and ${ }^{13} \mathrm{C}$ NMR spectra were measured in $\mathrm{CDCl}_{3}$ or $\mathrm{DMSO}-d_{6}$ on a 250 or $400 \mathrm{MHz}$ Brüker spectrometer. ${ }^{1} \mathrm{H}$ chemical shifts are reported in ppm from an internal standard TMS, residual chloroform (7.26 ppm) or DMSO- $d_{6}(2.50 \mathrm{ppm}) .{ }^{13} \mathrm{C}$ NMR chemical shifts are reported in ppm from an internal standard TMS, residual chloroform $(77.16 \mathrm{ppm})$ or DMSO- $d_{6}(39.43 \mathrm{ppm})$. High resolution ESI mass spectra were measured on a ThermoFisher Scientific Orbitrap XL system or with a resolution of 10000 on a Kratos MS50TC or a Kratos Mach III system. Low resolution ESI spectra were measured with an Agilent 1100 LC-MS/MS spectrometer. IR spectra were acquired on a Perkin-Elmer GX FTIR spectrophotometer as liquids between $\mathrm{NaCl}$ discs and are reported in wave numbers $\left(\mathrm{cm}^{-1}\right)$. Analytical thin layer chromatography was performed with Merck 70-230 mesh silica gel TLC plates. Purification of reaction products was generally done by dry-column 
flash chromatography using Merck silica gel 60 and/or flash chromatography using Carlo Erba Reactifs-SDS silica gel 60 .

\section{General Procedure for the synthesis of hydrazones 3a-e}

A stirred solution of 2-acetyl-1-naphthol $(0.8 \mathrm{~g}, 4.3 \mathrm{mmol})$, benzhydrazide, $p$-toluic hydrazide, 4methoxybenzhydrazide, 4-nitrobenzoic hydrazide or acetohydrazide $(4.7 \mathrm{mmol}$ ) and few drops of acetic acid were heated under reflux in propan-2-ol $(20 \mathrm{~mL})$ for 6 hours. The reaction mixture was cooled and the precipitated solid was collected and washed with cold propan-2-ol. The solid was purified and identified as described for the individual products $3 a-e$.

$N^{\prime}$-[(1E)-1-(1-Hydroxy-2-naphthyl)ethylidene]benzohydrazide (3a). Crystallised from propan-2-ol as yellow microcrystals $1.07 \mathrm{~g}$ (86\% yield); m.p. $252-253^{\circ} \mathrm{C} ; \mathrm{R}_{f} 0.11$ (25\% EtOAc/hexane); IR (KBr): $v_{\max } 3400,3178,1630$ $\mathrm{cm}^{-1} ;{ }^{1} \mathrm{H}$ NMR $\left(250 \mathrm{MHz}\right.$, DMSO-d 6 ): $\delta 2.60\left(\mathrm{~s}, 3 \mathrm{H}, \mathrm{CH}_{3}\right), 7.40(\mathrm{~d}, 1 \mathrm{H}, J 8.7 \mathrm{~Hz}, \mathrm{H}-4), 7.48-7.68(\mathrm{~m}, 5 \mathrm{H}, \mathrm{H}-6, \mathrm{H}-7$, H-3', H-4', H-5') 7.73 (d, 1H, J 9.0 Hz, H-3) 7.86 (dd, 1H, J 7.5, 1.2 Hz, H-5), 7.97 (d, 2H, J 6.7 Hz, H-2', H-6'), 8.35 (d, $1 \mathrm{H}, J 7.7 \mathrm{~Hz}, \mathrm{H}-8), 11.45$ (br s, $1 \mathrm{H}, \mathrm{NH}), 15.00(\mathrm{~s}, 1 \mathrm{H}, \mathrm{OH}) ;{ }^{13} \mathrm{C}$ NMR (63 MHz, DMSO-d $): \delta 14.45$, $112.14,117.48,123.10,124.76,124.95,125.32,127.22,127.81,128.08$ (2C), 128.39 (2C), 131.91, 132.95, 134.48, 156.38, 158.93, 164.29; HRMS (APCl): $m / z$ calcd. for $\mathrm{C}_{19} \mathrm{H}_{17} \mathrm{~N}_{2} \mathrm{O}_{2}[\mathrm{M}+\mathrm{H}]^{+} 305.1281$, found 305.1281; $\mathrm{m} / \mathrm{z}$ calcd. for $\mathrm{C}_{19} \mathrm{H}_{16} \mathrm{~N}_{2} \mathrm{NaO}_{2}[\mathrm{M}+\mathrm{Na}]^{+}$327.1097, found 327.1097.

$\mathbf{N}^{\prime}$-[(1E)-1-(1-Hydroxy-2-naphthyl)ethylidene]-4-methylbenzohydrazide (3b). Crystallised from propan-2-ol as yellow microcrystals $0.95 \mathrm{~g}$ (86\% yield); m.p. 239-240 ${ }^{\circ} \mathrm{C} ; \mathrm{R}_{f} 0.24$ (33\% EtOAc/hexane); IR (KBr): $v_{\max } 3400$, 3170, $1670 \mathrm{~cm}^{-1} ;{ }^{1} \mathrm{H}$ NMR (250 MHz, DMSO- $\left.d_{6}\right): \delta 2.40\left(\mathrm{~s}, 3 \mathrm{H}, \mathrm{CH}_{3}-4^{\prime}\right), 2.59\left(\mathrm{~s}, 3 \mathrm{H}, \mathrm{CH}_{3}\right), 7.30-7.42\left(\mathrm{~m}, 3 \mathrm{H}, \mathrm{H}-3^{\prime}\right.$, H-5', H-4), 7.44-7.60 (m, 2H, H-6, H-7), 7.71 (d, 1H, J 8.7 Hz, H-3), 7.80-7.93 (m, 3H, H-2', H-6', H-5), 8.34 (d, $1 \mathrm{H}$, J $7.7 \mathrm{~Hz}, \mathrm{H}-8), 11.36$ (br s, $1 \mathrm{H}, \mathrm{NH}), 15.07$ (br s, $1 \mathrm{H}, \mathrm{OH}) ;{ }^{13} \mathrm{C}$ NMR (63 MHz, DMSO-d $): \delta 14.89,21.52$, $112.69,117.98,123.58,125.22,125.43,125.80,127.70,128.26,128.59$ (2C), 129.40 (2C), 130.49, 134.94, 142.53, 156.76, 159.13, 164.56; HRMS (ESI): $m / z$ calcd. for $\mathrm{C}_{20} \mathrm{H}_{19} \mathrm{~N}_{2} \mathrm{O}_{2}[\mathrm{M}+\mathrm{H}]^{+} 319.1441$, found 319.1432.

$\mathbf{N}^{\prime}$-[(1E)-1-(1-Hydroxy-2-naphthyl)ethylidene]-4-methoxybenzohydrazide (3c). Crystallised from propan-2-ol as yellow microcrystals $1.08 \mathrm{~g}$ (75\% yield); m.p. $251-252{ }^{\circ} \mathrm{C} ; \mathrm{R}_{f} 0.26$ (50\% EtOAc/hexane); IR ( $\mathrm{KBr}$ ): $v_{\max } 3390$, 3180, $1620 \mathrm{~cm}^{-1} ;{ }^{1} \mathrm{H}$ NMR $\left(250 \mathrm{MHz}, \mathrm{DMSO}-d_{6}\right): \delta 2.58\left(\mathrm{~s}, 3 \mathrm{H}, \mathrm{CH}_{3}\right), 3.85\left(\mathrm{~s}, 3 \mathrm{H}, \mathrm{CH}_{3} \mathrm{O}\right), 7.09(\mathrm{~d}, 2 \mathrm{H}, J 8.5 \mathrm{~Hz}, \mathrm{H}-$ 3', H-5'), 7.39 (d, 1H, J 9.0 Hz, H-4), 7.48-7.62 (m, 2H, H-6, H-7), $7.72(\mathrm{~d}, 1 \mathrm{H}, J 8.7 \mathrm{~Hz}, \mathrm{H}-3), 7.85$ (d, $1 \mathrm{H}, J 7.2 \mathrm{~Hz}$, $\mathrm{H}-5), 7.96\left(\mathrm{~d}, 2 \mathrm{H}, J 8.7 \mathrm{~Hz}, \mathrm{H}-2^{\prime}, \mathrm{H}-6^{\prime}\right), 8.35$ (d, 1H, J $\left.7.7 \mathrm{~Hz}, \mathrm{H}-8\right), 11.28(\mathrm{~s}, 1 \mathrm{H}, \mathrm{NH}), 15.04(\mathrm{~s}, 1 \mathrm{H}, \mathrm{OH}) ;{ }^{13} \mathrm{C} \mathrm{NMR}$ $\left(63 \mathrm{MHz}, \mathrm{DMSO}-d_{6}\right): \delta 14.35,55.40,112.23,113.63(2 \mathrm{C}), 117.44,123.07,124.69,124.86,124.93,125.27$, 127.19, 127.71, 130.03 (2C), 134.40, 156.22, 158.21, 162.18, 163.62; HRMS (ESI): $\mathrm{m} / z$ calcd. for $\left[\mathrm{C}_{20} \mathrm{H}_{19} \mathrm{~N}_{2} \mathrm{O}_{3}\right]$ $[\mathrm{M}+\mathrm{H}]^{+}$335.1390, found 335.1392.

$N^{\prime}$-[(1E)-1-(1-Hydroxy-2-naphthyl)ethylidene]-4-nitrobenzohydrazide (3d). Crystallised from 2-methoxyethanol as orange needles $1.05 \mathrm{~g}$ (70\% yield); m.p.279-280 ${ }^{\circ} \mathrm{C} ; \mathrm{R}_{f} 0.23$ (50\% EtOAc/hexane); IR ( $\left.\mathrm{KBr}\right): v_{\max } 3384$, 3.082, 1688, 1520, $1344 \mathrm{~cm}^{-1}$; ${ }^{1} \mathrm{H}$ NMR $\left(400 \mathrm{MHz}\right.$, DMSO-d 6 ): $\delta 2.62\left(\mathrm{~s}, 3 \mathrm{H}, \mathrm{CH}_{3}\right), 7.42(\mathrm{~d}, 1 \mathrm{H}, J 8.8 \mathrm{~Hz}, \mathrm{H}-4), 7.54$ (dd, $1 \mathrm{H}, J 6.8 \mathrm{~Hz}, \mathrm{H}-7), 7.59$ (dd, $1 \mathrm{H}, J 6.8 \mathrm{~Hz}, \mathrm{H}-6), 7.74$ (d. $1 \mathrm{H}, J 8.8 \mathrm{~Hz}, \mathrm{H}-3), 7.87$ (d, $1 \mathrm{H}, J 8.0 \mathrm{~Hz}, \mathrm{H}-5), 8.21(\mathrm{~d}$, $\left.2 \mathrm{H}, J 8.8 \mathrm{~Hz}, \mathrm{H}-2^{\prime}, \mathrm{H}-6^{\prime}\right), 8.35$ (d, $\left.1 \mathrm{H}, J 8.0 \mathrm{~Hz}, \mathrm{H}-8\right), 8.40$ (d, 2H, J $\left.8.8 \mathrm{~Hz}, \mathrm{H}-3^{\prime}, \mathrm{H}-5^{\prime}\right), 11.74$ (s, 1H, NH), 14.83 (s, $1 \mathrm{H}, \mathrm{OH}) ;{ }^{13} \mathrm{C}$ NMR $\left(100.6 \mathrm{MHz}, \mathrm{DMSO}-d_{6}\right): \delta 14.66,112.05,117.67,123.12,123.48(2 \mathrm{C}), 124.79,125.42$, 127.23, 127.96, 129.66, (2C), 134.58, 138.64, 149.32, 156.37, 160.13, 162.76, 172.25; HRMS (ESI): $\mathrm{m} / \mathrm{z} \mathrm{calcd}$. for $\left[\mathrm{C}_{19} \mathrm{H}_{16} \mathrm{~N}_{3} \mathrm{O}_{4}\right][\mathrm{M}+\mathrm{H}]^{+} 350.1135$, found 350.1127 .

$\mathbf{N}^{\prime}$-[(1E)-1-(1-Hydroxy-2-naphthyl)ethylidene]acetohydrazide (3e). Crystallised from propan-2-ol as orange microcrystals $1.62 \mathrm{~g}$ (60\% yield); m.p. $243-244{ }^{\circ} \mathrm{C}$; $\mathrm{R}_{f} 0.09$ (50\% EtOAc/hexane); IR (KBr): $v_{\max } 3350,3140,1640$ $\mathrm{cm}^{-1}$; ${ }^{1} \mathrm{H}$ NMR $\left(250 \mathrm{MHz}\right.$, DMSO- $\left.d_{6}\right): \delta 2.11\left(\mathrm{~s}, 3 \mathrm{H}, \mathrm{CH}_{3} \mathrm{CO}\right), 2.47\left(\mathrm{~s}, 3 \mathrm{H}, \mathrm{CH}_{3}\right), 7.38(\mathrm{~d}, 1 \mathrm{H}, J 8.7 \mathrm{~Hz}, \mathrm{H}-4), 7.46-$ $7.60(\mathrm{~m}, 2 \mathrm{H}, \mathrm{H}-6, \mathrm{H}-7), 7.67$ (d, $1 \mathrm{H}, J 8.7 \mathrm{~Hz}, \mathrm{H}-3), 7.83$ (dd, 1H, J 7.5, $1.2 \mathrm{~Hz}, \mathrm{H}-5), 8.30(\mathrm{~d}, 1 \mathrm{H}, J 7.7 \mathrm{~Hz}, \mathrm{H}-8)$, $11.03(\mathrm{~s}, 1 \mathrm{H}, \mathrm{NH}), 14.82(\mathrm{~s}, 1 \mathrm{H}, \mathrm{OH}) ;{ }^{13} \mathrm{C}$ NMR (63 MHz, DMSO-d $): \delta$ 13.81, 21.07, 112.14, 117.44, 122.97, $124.64,124.88,125.27,127.18,127.61,134.27,154.84,155.80,166.19 ; \mathrm{HRMS}$ (ESI): calcd. for $\left[\mathrm{C}_{14} \mathrm{H}_{15} \mathrm{~N}_{2} \mathrm{O}_{2}\right][\mathrm{M}$ $+\mathrm{H}]^{+}$243.1128, found 243.1121 . 


\section{General Procedure 1. Oxidation of 3a-e by CAN (1.1 equiv) for the preparation of $4 a-e, 5 a-d$ and 6}

To a stirred solution of appropriate hydrazone 3a-e $(1.5 \mathrm{mmol})$ in dry acetonitrile $(20 \mathrm{~mL})$ under an atmosphere of $\mathrm{N}_{2}$, CAN ( $\left.0.88 \mathrm{~g}, 1.6 \mathrm{mmol}\right)$ was added and the resulting mixture was stirred at room temperature for 1 hour. TLC examination revealed the disappearance of starting material spot and appearance of 3 new spots. The reaction mixture was cooled and the precipitated solid was filtered and washed with cold acetonitrile. Recrystallisation from acetonitrile or $\mathrm{DMSO} / \mathrm{H}_{2} \mathrm{O}$ afforded products $4 a-e$. The filtrate was concentrated in vacuo, water $(25 \mathrm{~mL})$ was added and extracted with ethyl acetate $(3 \times 10 \mathrm{~mL})$. The combined organic layers were dried over anhydrous sodium sulfate and the solvent evaporated in vacuo. The oily residue was purified by flash chromatography (ethyl acetate/hexane, $1: 6$ ) to give products $\mathbf{5 a - d}$ and $\mathbf{6}$. The yields of products $\mathbf{4 a - e}$, $\mathbf{5 a}-\mathbf{d}$ and $\mathbf{6}$ are presented in Table 1.

$N^{\prime}$-[(1E)-1-(1-Hydroxy-4-nitro-2-naphthyl)ethylidene]benzohydrazide (4a). Crystallised from acetonitrile as yellow needles $0.23 \mathrm{~g}$ (47\% yield); m.p. $254-255^{\circ} \mathrm{C} ; \mathrm{R}_{f} 0.15$ (50\% EtOAc/hexane); IR ( $\left.\mathrm{KBr}\right): v_{\max } 3366,3208$, $1672,1652,1518,1302 \mathrm{~cm}^{-1} ;{ }^{1} \mathrm{H}$ NMR $\left(250 \mathrm{MHz}, \mathrm{DMSO}-d_{6}\right): \delta 2.70\left(\mathrm{~s}, 3 \mathrm{H}, \mathrm{CH}_{3}\right), 7.50-7.65\left(\mathrm{~m}, 3 \mathrm{H}, \mathrm{H}-3^{\prime}, \mathrm{H}-4^{\prime}, \mathrm{H}-\right.$ $5^{\prime}$ ), $7.70(\mathrm{dd}, 1 \mathrm{H}, J 8.0 \mathrm{~Hz}, \mathrm{H}-7), 7.87$ (dd, $\left.1 \mathrm{H}, J 7.7 \mathrm{~Hz}, \mathrm{H}-6\right), 8.00$ (d, 2H, J $\left.6.7 \mathrm{~Hz}, \mathrm{H}-2^{\prime}, \mathrm{H}-6{ }^{\prime}\right), 8.55$ (d, $1 \mathrm{H}, J 8.5$ $\mathrm{Hz}, \mathrm{H}-5), 8.67$ (d, $1 \mathrm{H}, J 8.5 \mathrm{~Hz}, \mathrm{H}-8), 8.73$ (s, 1H, H-3), 11.78 (br s, $1 \mathrm{H}, \mathrm{NH}), 16.57$ (br s, $1 \mathrm{H}, \mathrm{OH}) .{ }^{13} \mathrm{C} \mathrm{NMR}(63$ $\left.\mathrm{MHz}, \mathrm{DMSO}-d_{6}\right): \delta 14.69,110.68,123.37,124.98,126.53,127.00,127.28,127.63,128.61(2 \mathrm{C}), 128.81(2 \mathrm{C})$, $131.92,132.35,133.56,135.14,157.44,165.43,165.61 ; \mathrm{HRMS}(\mathrm{ESI}): \mathrm{m} / \mathrm{z}$ calcd. for $\left[\mathrm{C}_{19} \mathrm{H}_{16} \mathrm{~N}_{3} \mathrm{O}_{4}\right][\mathrm{M}+\mathrm{H}]^{+}$ 350.1135 , found 350.1128; $\mathrm{m} / z$ calcd. for $\left[\mathrm{C}_{19} \mathrm{H}_{15} \mathrm{~N}_{3} \mathrm{NaO}_{4}\right][\mathrm{M}+\mathrm{Na}]^{+} 372.0955$, found 372.0946 .

1-(1-Benzoyl-4-nitro-2-naphthyl)ethanone (5a). Crystallised from $\mathrm{CH}_{2} \mathrm{Cl}_{2}$ /hexane as colourless microcrystals $0.15 \mathrm{~g}$ (32\% yield); m.p. $150-151{ }^{\circ} \mathrm{C}(\mathrm{dec}) ; \mathrm{R}_{f} 0.30$ (25\% EtOAc/hexane); IR (KBr): $v_{\max } 1674,1522,1360 \mathrm{~cm}^{-1} ;{ }^{1} \mathrm{H}$ NMR (400 MHz, CDCl 3 ): $\delta 2.69\left(\mathrm{~s}, 3 \mathrm{H}, \mathrm{CH}_{3}\right), 7.40-7.46\left(\mathrm{~m}, 2 \mathrm{H}, \mathrm{H}-3^{\prime}, \mathrm{H}-5^{\prime}\right), 7.55-7.65\left(\mathrm{~m}, 2 \mathrm{H}, \mathrm{H}-7, \mathrm{H}-4^{\prime}\right), 7.73(\mathrm{~d}$, $2 \mathrm{H}$, J $\left.7.2 \mathrm{~Hz}, \mathrm{H}-2^{\prime}, \mathrm{H}-6^{\prime}\right), 7.80-7.89(\mathrm{~m}, 2 \mathrm{H}, \mathrm{H}-5, \mathrm{H}-6), 8.63$ (d, $\left.1 \mathrm{H}, J 8.8 \mathrm{~Hz}, \mathrm{H}-8\right), 8.68(\mathrm{~s}, 1 \mathrm{H}, \mathrm{H}-3) ;{ }^{13} \mathrm{C} \mathrm{NMR}$ $\left(100.6 \mathrm{MHz}, \mathrm{CDCl}_{3}\right): \delta 27.66,122.66,123.43,126.72,128.14,128.69$ (2C), 128.89 (2C), 129.10, 130.70, 131.86, 131.96, 133.74, 137.06, 145.75, 147.04, 195.68, 196.93; HRMS (EI): $\mathrm{m} / z$ calcd. for $\mathrm{C}_{19} \mathrm{H}_{13} \mathrm{NO}_{4} 319.08446$, found 319.08432.

3-Methyl-5-nitronaphtho[2,1-d] isoxazole (6). Crystallised from $\mathrm{CH}_{2} \mathrm{Cl}_{2}$ /hexane as colourless microcrystals $0.061 \mathrm{~g}$ (18\% yield); m.p. 179-180 ${ }^{\circ} \mathrm{C} ; \mathrm{R}_{f} 0.40$ (20\% EtOAc/hexane); IR (KBr): $v_{\max } 1638,1520,1348,768 \mathrm{~cm}^{-1} ;{ }^{1} \mathrm{H}$ NMR $\left(250 \mathrm{MHz}_{\mathrm{CDCl}}\right): \delta 2.71\left(\mathrm{~s}, 3 \mathrm{H}, \mathrm{CH}_{3}\right), 7.77-7.92(\mathrm{~m}, 2 \mathrm{H}, \mathrm{H}-7, \mathrm{H}-8), 8.47(\mathrm{~s}, 1 \mathrm{H}, \mathrm{H}-4), 8.48(\mathrm{~d}, 1 \mathrm{H}, J 8.5 \mathrm{~Hz}$, $\mathrm{H}-6), 8.69$ (d, $1 \mathrm{H}, J 8.0 \mathrm{~Hz}, \mathrm{H}-9) ;{ }^{13} \mathrm{C} \mathrm{NMR}\left(63 \mathrm{MHz}, \mathrm{CDCl}_{3}\right): \delta 10.09,115.34,118.05,119.37,122.51,124.56$, 125.72, 128.60, 130.81, 143.96, 156.66, 162.95; HRMS (El): $\mathrm{m} / z$ calcd. for $\mathrm{C}_{12} \mathrm{H}_{8} \mathrm{~N}_{2} \mathrm{O}_{3}$ 228.05349, found 228.05395.

$N^{\prime}$-[(1E)-1-(1-Hydroxy-4-nitro-2-naphthyl)ethylidene]-4-methylbenzohydrazide (4b). Crystallised from acetonitrile as pale green microcrystals $0.26 \mathrm{~g}\left(50 \%\right.$ yield); m.p. $254{ }^{\circ} \mathrm{C}(\mathrm{dec}) ; \mathrm{R}_{f} 0.10$ (50\% EtOAc/hexane); $\mathrm{IR}(\mathrm{KBr})$ : $v_{\max } 3218,2924,1642,1610,1500,1310 \mathrm{~cm}^{-1}$; ${ }^{1} \mathrm{H}$ NMR $\left(400 \mathrm{MHz}, \mathrm{DMSO}-d_{6}\right): \delta 2.41\left(\mathrm{~s}, 3 \mathrm{H}, \mathrm{CH}_{3}-4^{\prime}\right), 2.68(\mathrm{~s}, 3 \mathrm{H}$, $\left.\mathrm{CH}_{3}\right), 7.38\left(\mathrm{~d}, 2 \mathrm{H}, J 8.0 \mathrm{~Hz}, \mathrm{H}-3^{\prime}, \mathrm{H}-5^{\prime}\right), 7,72(\mathrm{dd}, 1 \mathrm{H}, J 8.0 \mathrm{~Hz}, \mathrm{H}-7), 7.84-7.94\left(\mathrm{~m}, 3 \mathrm{H}, \mathrm{H}-2^{\prime}, \mathrm{H}-6^{\prime}, \mathrm{H}-6\right), 8.54(\mathrm{~d}$, $1 \mathrm{H}, J 8.4 \mathrm{~Hz}, \mathrm{H}-5), 8.64$ (d, 1H, J $8.4 \mathrm{~Hz}, \mathrm{H}-8), 8.71$ (s, $1 \mathrm{H}, \mathrm{H}-3), 11.66$ (br s, $1 \mathrm{H}, \mathrm{NH}), 16.59$ (br s, $1 \mathrm{H}, \mathrm{OH}) ;{ }^{13} \mathrm{C}$ NMR $\left(63 \mathrm{MHz}\right.$, DMSO- $\left.d_{6}\right): \delta 14.80,21.55,110.87,123.31,124.76,126.02(2 \mathrm{C}), 127.01,127.26,128.72(2 \mathrm{C})$, 129.44 (2C), 129.93, 131.98, 136.16, 142.90, 158.04, 164.19, 164.85; HRMS (ESI): $\mathrm{m} / z$ calcd. for $\left[\mathrm{C}_{20} \mathrm{H}_{17} \mathrm{~N}_{3} \mathrm{O}_{4}\right]$ $[\mathrm{M}+\mathrm{H}]^{+} 364.1292$, found $364.1287 ; \mathrm{m} / \mathrm{z}$ calcd. for $\left[\mathrm{C}_{20} \mathrm{H}_{17} \mathrm{~N}_{3} \mathrm{NaO}_{4}\right][\mathrm{M}+\mathrm{Na}]^{+}$386.1111, found 386.1104.

1-[1-(4-Methylbenzoyl)-4-nitro-2-naphthyl]ethanone (5b). Crystallised from $\mathrm{CH}_{2} \mathrm{Cl}_{2} /$ hexane as yellow microcrystals $0.14 \mathrm{~g}$ ( $28 \%$ yield); m.p. $142-143^{\circ} \mathrm{C}$ (dec); $\mathrm{R}_{f} 0.39$ (50\% EtOAc/hexane); IR (KBr): $v_{\max } 1686,1678$,

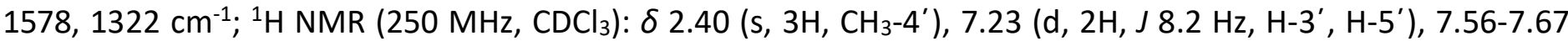
$\left(\mathrm{m}, 3 \mathrm{H}, \mathrm{H}-2^{\prime}, \mathrm{H}-6^{\prime}, \mathrm{H}-7\right), 7.80-7.90(\mathrm{~m}, 2 \mathrm{H}, \mathrm{H}-5, \mathrm{H}-6), 8.62(\mathrm{~d}, 1 \mathrm{H}, \mathrm{J} 8.5 \mathrm{~Hz}, \mathrm{H}-8), 8.68(\mathrm{~s}, 1 \mathrm{H}, \mathrm{H}-3) ;{ }^{13} \mathrm{C}$ NMR $(63$ $\left.\mathrm{MHz}_{1} \mathrm{CDCl}_{3}\right): \delta 21.78,27.76,122.69,123.39,126.70,128.21,128.87$ (2C), 129.01, 129.63 (2C), 130.71, 131.88 (2C), 134.75, 144.84, 145.89, 146.98, 195.69, 196.55; HRMS (El): $\mathrm{m} / z$ calcd. for $\mathrm{C}_{20} \mathrm{H}_{15} \mathrm{NO}_{4} 333.1001$, found 333.1009 . 
3-Methyl-5-nitronaphtho[2,1-d]isoxazole (6). Obtained $0.064 \mathrm{~g}$ (19\% yield). It was identified by comparing its ${ }^{1} \mathrm{H}$ NMR spectrum with the corresponding spectrum of an authentic sample.

$N^{\prime}$-[(1E)-1-(1-Hydroxy-4-nitro-2-naphthyl)ethylidene]-4-methoxybenzohydrazide (4c). Crystallised from acetonitrile as yellow microcrystals $0.26 \mathrm{~g}$ (48\% yield); m.p. $249{ }^{\circ} \mathrm{C}(\mathrm{dec}) ; \mathrm{R}_{f} 0.09(50 \%$ EtOAc/hexane); IR (KBr): $v_{\max } 3444,3198,1640,1608,1498,1304,1258 \mathrm{~cm}^{-1}$; ${ }^{1} \mathrm{H}$ NMR $\left(250 \mathrm{MHz}, \mathrm{DMSO}-d_{6}\right): \delta 2.67\left(\mathrm{~s}, 3 \mathrm{H}, \mathrm{CH}_{3}\right), 3.86(\mathrm{~s}$, $3 \mathrm{H}, \mathrm{CH}_{3} \mathrm{O}$ ), 7.10 (d, $2 \mathrm{H}, J 8.7 \mathrm{~Hz}, \mathrm{H}-3^{\prime}, \mathrm{H}-5^{\prime}$ ), 7.70 (dd, $\left.1 \mathrm{H}, J 7.7 \mathrm{~Hz}, \mathrm{H}-7\right), 7.87$ (dd, $\left.1 \mathrm{H}, J 8.0 \mathrm{~Hz}, \mathrm{H}-6\right), 8.00$ (d, $2 \mathrm{H}$, J $\left.8.7 \mathrm{~Hz}, \mathrm{H}-2^{\prime}, \mathrm{H}-6^{\prime}\right), 8.54(\mathrm{~d}, 1 \mathrm{H}, J 8.2 \mathrm{~Hz}, \mathrm{H}-5), 8.66$ (d, $\left.1 \mathrm{H}, J 8.5 \mathrm{~Hz}, \mathrm{H}-8\right), 8.72(\mathrm{~s}, 1 \mathrm{H}, \mathrm{H}-3), 11.62$ (br s, 1H, NH), 16.64 (br s, $1 \mathrm{H}, \mathrm{OH}) ;{ }^{13} \mathrm{C} \mathrm{NMR}(63 \mathrm{MHz}$, DMSO-d $): \delta 14.72,55.93,110.82,114.15(2 \mathrm{C}), 123.34,124.87,125.09$, 126.30, 127.12, 127.31, 130.65 (2C), 131.93, 135.65, 157.38, 162.82, 164.58, 164.94, 165.16; HRMS (ESI): $\mathrm{m} / \mathrm{z}$ calcd. for $\left[\mathrm{C}_{20} \mathrm{H}_{16} \mathrm{~N}_{3} \mathrm{O}_{5}\right][\mathrm{M}-\mathrm{H}]^{-}$378.1090, found 378.1094.

1-[1-(4-Methoxybenzoyl)-4-nitro-2-naphthyl]ethanone (5c). Crystallised from $\mathrm{CH}_{2} \mathrm{Cl}_{2}$ /hexane as yellow microcrystals $0.16 \mathrm{~g}$ (30\% yield); m.p. $169-170{ }^{\circ} \mathrm{C} ; \mathrm{R}_{f} 0.33$ (50\% EtOAc/hexane); IR ( $\left.\mathrm{KBr}\right): v_{\max } 1690,1670,1598$, 1306, $1248 \mathrm{~cm}^{-1}$; ${ }^{1} \mathrm{H}$ NMR (250 MHz, DMSO-d $\left.)_{6}\right): \delta 2.70\left(\mathrm{~s}, 3 \mathrm{H}, \mathrm{CH}_{3}\right), 3.82\left(\mathrm{~s}, 3 \mathrm{H}, \mathrm{CH}_{3} \mathrm{O}\right), 6.99(\mathrm{~d}, 2 \mathrm{H}, J 8.5 \mathrm{~Hz}, \mathrm{H}-$ 3' , H-5'), 7.59-7.79 (m, 4H, H-5, H-7, H-2', H-6'), 7.92 (dd, 1H, J 7.0 Hz, H-6), 8.41 (d, 1H, J 8.7 Hz, H-8), 8.89 (s, $1 \mathrm{H}, \mathrm{H}-3) ;{ }^{13} \mathrm{C}$ NMR $\left(63 \mathrm{MHz}, \mathrm{CDCl}_{3}\right): \delta 27.91,55.54,114.18(2 \mathrm{C}), 122.74,123.35,126.66,128.23,128.97$, $130.38,130.68,131.14$ (2C), 131.85, 132.32, 145.82, 146.89, 164.06, 195.48, 195.80; HRMS (El): $\mathrm{m} / \mathrm{z}$ calcd. for $\mathrm{C}_{20} \mathrm{H}_{15} \mathrm{NO}_{5} 349.0950$, found 349.0979 .

3-Methyl-5-nitronaphtho[2,1-d]isoxazole (6). Obtained $0.068 \mathrm{~g}$ (20\% yield). It was identified by comparing its ${ }^{1} \mathrm{H}$ NMR spectrum with the corresponding spectrum of an authentic sample.

$N^{\prime}$-[(1E)-1-(1-Hydroxy-4-nitro-2-naphthyl)ethylidene]-4-nitrobenzohydrazide $\quad$ (4d). Crystallised from DMSO $/ \mathrm{H}_{2} \mathrm{O}$ as pale green microcrystals $0.28 \mathrm{~g}$ (52\% yield); m.p. 259-260 ${ }^{\circ} \mathrm{C} ; \mathrm{R}_{f} 0.15$ (33\% EtOAc/hexane); IR $(\mathrm{KBr}): v_{\max } 3364,3104,1686,1600,1522,1510,1308 \mathrm{~cm}^{-1} ;{ }^{1} \mathrm{H}$ NMR $\left(250 \mathrm{MHz}, \mathrm{DMSO}-d_{6}\right): \delta 2.69\left(\mathrm{~s}, 3 \mathrm{H}, \mathrm{CH}_{3}\right)$, 7.72 (dd, $1 \mathrm{H}, J 7.7 \mathrm{~Hz}, \mathrm{H}-7), 7.88$ (dd, $1 \mathrm{H}, J 7.2 \mathrm{~Hz}, \mathrm{H}-6), 8.21$ (d, 2H, J $8.5 \mathrm{~Hz}, \mathrm{H}-2^{\prime}, \mathrm{H}-6$ '), 8.39 (d, $2 \mathrm{H}, J 8.7 \mathrm{~Hz}, \mathrm{H}-$ 3', H-5'), 8.53 (d, 1H, J $8.2 \mathrm{~Hz}, \mathrm{H}-5), 8.62$ (d, 1H, J $8.5 \mathrm{~Hz}, \mathrm{H}-8), 8.70$ (s, 1H, H-3), 12.03 (br s, 1H, NH), 16.32 (br s, $1 \mathrm{H}, \mathrm{OH}) ;{ }^{13} \mathrm{C}$ NMR $\left(63 \mathrm{MHz}\right.$, DMSO- $\left.d_{6}\right): \delta 14.47,110.30,122.77,123.41(2 \mathrm{C}), 124.21,125.37,126.47,126.79$ (2C), 129.71 (2C), 131.52, 135.81, 138.15, 149.38, 158.47, 163.00, 163.30; HRMS (APCl): $\mathrm{m} / \mathrm{z}$ calcd. for $\mathrm{C}_{19} \mathrm{H}_{13} \mathrm{~N}_{4} \mathrm{O}_{6}[\mathrm{M}-\mathrm{H}]^{-} 393.0824$, found 393.0824 .

1-[4-Nitro-1-(4-nitrobenzoyl)-2-naphthyl]ethanone (5d). Crystallised from $\mathrm{CH}_{2} \mathrm{Cl}_{2} / \mathrm{hexane}$ as yellow microcrystals $0.16 \mathrm{~g}$ (30\% yield); m.p. $187-188^{\circ} \mathrm{C} ; \mathrm{R}_{f} 0.30$ (50\% EtOAc/hexane); IR ( $\left.\mathrm{KBr}\right): v_{\max } 1688,1682,1520$, 1356, $1346 \mathrm{~cm}^{-1}$; ${ }^{1} \mathrm{H}$ NMR $\left(250 \mathrm{MHz}, \mathrm{CDCl}_{3}\right): \delta 2.72\left(\mathrm{~s}, 3 \mathrm{H}, \mathrm{CH}_{3}\right), 7.62-7.78(\mathrm{~m}, 2 \mathrm{H}, \mathrm{H}-5, \mathrm{H}-7), 7.84-7.96(\mathrm{~m}, 3 \mathrm{H}$, $\left.\mathrm{H}-6, \mathrm{H}-2^{\prime}, \mathrm{H}-6^{\prime}\right), 8.28\left(\mathrm{~d}, 2 \mathrm{H}, \mathrm{J} 9.0 \mathrm{~Hz}, \mathrm{H}-3^{\prime}, \mathrm{H}-5^{\prime}\right), 8.66$ (d, $\left.1 \mathrm{H}, J 8.7 \mathrm{~Hz}, \mathrm{H}-8\right), 8.70(\mathrm{~s}, 1 \mathrm{H}, \mathrm{H}-3) ;{ }^{13} \mathrm{C} \mathrm{NMR}(63 \mathrm{MHz}$, $\left.\mathrm{CDCl}_{3}\right): \delta$ 27.32, 122.42, 123.74, 124.14 (2C), 126.86, 127.50, 129.36 (2C), 129.55, 130.83, 131.54, 132.28, 141.36, 144.25, 147.52, 150.43, 195.07, 195.85; HRMS (APCI): $\mathrm{m} / \mathrm{z}$ calcd. for $\mathrm{C}_{19} \mathrm{H}_{11} \mathrm{~N}_{2} \mathrm{O}_{6}[\mathrm{M}-\mathrm{H}]^{-} 363.0608$, found 363.0609 .

3-Methyl-5-nitronaphtho[2,1-d]isoxazole (6). Obtained $0.05 \mathrm{~g}$ (15\% yield). It was identified by comparing its ${ }^{1} \mathrm{H}$ NMR spectrum with the corresponding spectrum of an authentic sample.

$\mathbf{N}^{\prime}$-[(1E)-1-(1-Hydroxy-4-nitro-2-naphthyl)ethylidene]acetohydrazide (4e). Crystallised from acetonitrile as light brown microcrystals 0.20 g (50\% yield); m.p. $265^{\circ} \mathrm{C}(\mathrm{dec}) ; \mathrm{R}_{f} 0.05$ (67\% EtOAc/hexane); $\mathrm{IR}(\mathrm{KBr}): v_{\max }$ $3248,1674,1632,1514,1304 \mathrm{~cm}^{-1}$; ${ }^{1} \mathrm{H}$ NMR $(400 \mathrm{MHz}$, DMSO-d $): \delta 2.13,\left(\mathrm{~s}, 3 \mathrm{H}, \mathrm{CH}_{3} \mathrm{CO}\right), 2.54\left(\mathrm{~s}, 3 \mathrm{H}, \mathrm{CH}_{3}\right), 7.70$ (ddd, $1 \mathrm{H}, J$ 8.0, 7.2, $0.8 \mathrm{~Hz}, \mathrm{H}-7$ ), 7.86 (ddd, 1H, J 8.4, 7.2, 1.2 Hz, H-6), 8.50 (d, 1H, J 8.4 Hz, H-5), 8.62 (d, $1 \mathrm{H}, J$ $8.8 \mathrm{~Hz}, \mathrm{H}-8), 8.65$ (s, $1 \mathrm{H}, \mathrm{H}-3), 11.35$ (br s, $1 \mathrm{H}, \mathrm{NH}), 16.38$ (br s, $1 \mathrm{H}, \mathrm{OH}) ;{ }^{13} \mathrm{C}$ NMR $\left(100.6 \mathrm{MHz}, \mathrm{DMSO}-d_{6}\right): \delta$ $13.73,20.93,110.51,122.76,124.09,125.28,126.19,126.29,126.78,131.38,135.84,153.93,162.76,166.50$. HRMS (ESI): $m / z$ calcd. for $\left[\mathrm{C}_{14} \mathrm{H}_{14} \mathrm{~N}_{3} \mathrm{O}_{4}\right][\mathrm{M}+\mathrm{H}]^{+} 288.0979$, found 288.0977 .

3-Methyl-5-nitronaphtho[2,1-d]isoxazole (6). Obtained $0.10 \mathrm{~g}$ (30\% yield). It was identified by comparing its ${ }^{1} \mathrm{H}$ NMR spectrum with the corresponding spectrum of an authentic sample. 
General Procedure 2. Oxidation of 3a-e by CAN (1.1 equiv) followed by addition of CAN (1.1 equiv) for the preparation of $5 a-d$ and 6

To a stirred solution of appropriate hydrazone $3 a-e(1.5 \mathrm{mmol})$ in dry acetonitrile $(25 \mathrm{~mL})$ under an atmosphere of $\mathrm{N}_{2}$, CAN $(0.88 \mathrm{~g}, 1.6 \mathrm{mmol})$ was added and the resulting mixture was stirred at room temperature for 1 hour. TLC examination revealed the disappearance of starting material spot and appearance of 3 spots corresponding to $4 \mathbf{a}-\mathbf{e}, 5 \mathbf{a}-\mathbf{d}$ and $\mathbf{6}$. CAN $(0.88 \mathrm{~g}, 1.6 \mathrm{mmol})$ was added and the reaction mixture stirred for 1 hour at room temperature. TLC examination revealed the appearance of spots corresponding to $\mathbf{5 a - d}$ and $\mathbf{6}$. The work up and purification of products $\mathbf{5 a - d}$ and $\mathbf{6}$ was carried out as in the General Procedure 1. They were identified by comparing their ${ }^{1} \mathrm{H}$ NMR spectra with the corresponding spectra of authentic samples while their yields are depicted in Table 2.

\section{General Procedure 3. Oxidation of 3a-e by CAN (2.2 equiv) for the preparation of 5a-d and 6}

To a stirred solution of appropriate hydrazone 1a-e $(1.5 \mathrm{mmol})$ in dry acetonitrile $(25 \mathrm{~mL}) \mathrm{under}$ an atmosphere of $\mathrm{N}_{2}$, CAN $(1.76 \mathrm{~g}, 3.2 \mathrm{mmol})$ was added and the resulting mixture was stirred at room temperature for 2 hours. TLC examination revealed the appearance of spots corresponding to $\mathbf{5 a - d}$ and $\mathbf{6}$. The work up and purification of products $\mathbf{5 a}-\mathbf{d}$ and $\mathbf{6}$ was carried out as in the General Procedure 1 . They were identified by comparing their ${ }^{1} \mathrm{H}$ NMR spectra with the corresponding spectra of authentic samples while their yields are shown in Table 3.

Condensation of diacyl derivatives $5 a-d$ with hydrazine hydrate; preparation of $7 a-d$

A mixture of diacyl compound $5 \mathbf{a}-\mathbf{d}(0.60 \mathrm{mmol})$ and hydrazine hydrate $(0.03 \mathrm{~g}, 0.60 \mathrm{mmol})$ was stirred at room temperature in propan-2-ol $(8 \mathrm{~mL})$ for $2 \mathrm{~h}$ and then cooled. The resulting precipitate was filtered off, washed with cold propan-2-ol and recrystallized from the same solvent to give the corresponding benzo[f]phthalazines 7a-d.

4-Methyl-6-nitro-1-phenylbenzo[f]phthalazine (7a). Crystallised from propan-2-ol as orange microcrystals $0.16 \mathrm{~g}$ (89\% yield); m.p. 190-192 ${ }^{\circ} \mathrm{C} ; \mathrm{R}_{f} 0.25$ (50\% EtOAc/hexane); IR (KBr): $v_{\max } 1618,1528,1394 \mathrm{~cm}^{-1} ;{ }^{1} \mathrm{H} \mathrm{NMR}$ $\left(250 \mathrm{MHz} \mathrm{CDCl}_{3}\right): \delta 3.18\left(\mathrm{~s}, 3 \mathrm{H}, \mathrm{CH}_{3}\right), 7.42$ (dd, 1H, J 8.2, $\left.1.0 \mathrm{~Hz}, \mathrm{H}-9\right), 7.51-7.64$ (m, 5H, H-2', H-3', H-4', H-5', $\left.\mathrm{H}^{\prime} 6^{\prime}\right), 7.78(\mathrm{dd}, 1 \mathrm{H}, J$ 8.2, $1.0 \mathrm{~Hz}, \mathrm{H}-8), 8.03(\mathrm{~d}, 1 \mathrm{H}, J 8.5 \mathrm{~Hz}, \mathrm{H}-7), 8.33$ (d, 1H, J $\left.8.2 \mathrm{~Hz}, \mathrm{H}-10\right), 8.53$ (s, 1H, H-5); ${ }^{13} \mathrm{C} \mathrm{NMR}\left(63 \mathrm{MHz}, \mathrm{CDCl}_{3}\right): \delta 20.15,117.97,123.45,124.71,124.89,125.90,128.14,128.53,129.12(2 \mathrm{C}), 129.29$ (2C), 129.40, 129.47, 130.47, 139.98, 150.58, 156.14, 157.54; HRMS (ESI): $m / z$ calcd. for $\left[\mathrm{C}_{19} \mathrm{H}_{14} \mathrm{~N}_{3} \mathrm{O}_{2}\right][\mathrm{M}+\mathrm{H}]^{+}$ 316.1081, found 316.1081.

4-Methyl-1-(4-methylphenyl)-6-nitrobenzo[f]phthalazine (7b). Crystallised from propan-2-ol as yellow microcrystals $0.19 \mathrm{~g}$ (98\% yield); m.p. $211-212^{\circ} \mathrm{C}$; $\mathrm{R}_{f} 0.13$ (33\% EtOAc/hexane); IR (KBr): $v_{\max } 1620,1530,1394$ $\mathrm{cm}^{-1} ;{ }^{1} \mathrm{H}$ NMR $\left(250 \mathrm{MHz}, \mathrm{CDCl}_{3}\right): \delta 2.49\left(\mathrm{~s}, 3 \mathrm{H}, \mathrm{CH}_{3}-4^{\prime}\right), 3.17\left(\mathrm{~s}, 3 \mathrm{H}, \mathrm{CH}_{3}-4\right), 7.34\left(\mathrm{~d}, 2 \mathrm{H}, J 8.0 \mathrm{~Hz}, \mathrm{H}-3^{\prime}, \mathrm{H}-5^{\prime}\right), 7.44$ (dd, $1 \mathrm{H}, J 8.2,1.0 \mathrm{~Hz}, \mathrm{H}-9), 7.50\left(\mathrm{~d}, 2 \mathrm{H}, J 8.0 \mathrm{~Hz}, \mathrm{H}-2^{\prime}, \mathrm{H}-6^{\prime}\right), 7.78(\mathrm{dd}, 1 \mathrm{H}, J 8.0,0.8 \mathrm{~Hz}, \mathrm{H}-8), 8.12$ (d, $1 \mathrm{H}, J 8.7$ $\mathrm{Hz}, \mathrm{H}-7), 8.33$ (d, $1 \mathrm{H}, J 8.2 \mathrm{~Hz}, \mathrm{H}-10), 8.52(\mathrm{~s}, 1 \mathrm{H}, \mathrm{H}-5) ;{ }^{13} \mathrm{C} \mathrm{NMR}\left(63 \mathrm{MHz}, \mathrm{CDCl}_{3}\right): \delta 20.11,21.44,117.98$, 123.38, 124.69, 124.89, 125.88, 128.05, 128.54, 129.03 (2C), 129.62, 129.96 (2C), 130.40, 137.08, 139.46, 150.50, 155.88, 157.56; HRMS (ESI): $m / z$ calcd. for $\left[\mathrm{C}_{20} \mathrm{H}_{16} \mathrm{~N}_{3} \mathrm{O}_{2}\right][\mathrm{M}+\mathrm{H}]^{+} 330.1237$, found 330.1237.

1-(4-Methoxyphenyl)-4-methyl-6-nitrobenzo[f]phthalazine (7c). Crystallised from propan-2-ol as yellow microcrystals $0.21 \mathrm{~g}$ (98\% yield); m.p. $219-220^{\circ} \mathrm{C} ; \mathrm{R}_{f} 0.14$ (50\% EtOAc/hexane); IR ( $\mathrm{KBr}$ ): $v_{\max } 1614,1516,1392$, $1252 \mathrm{~cm}^{-1}$; ${ }^{1} \mathrm{H}$ NMR $\left(250 \mathrm{MHz} \mathrm{CDCl}_{3}\right): \delta 3.16\left(\mathrm{~s}, 3 \mathrm{H}, \mathrm{CH}_{3}\right), 3.92\left(\mathrm{~s}, 3 \mathrm{H}, \mathrm{CH}_{3} \mathrm{O}\right), 7.06\left(\mathrm{~d}, 2 \mathrm{H}, J 8.7 \mathrm{~Hz}, \mathrm{H}-3^{\prime}, \mathrm{H}-5^{\prime}\right)$, $7.46(\mathrm{dd}, 1 \mathrm{H}, J$ 8.2, $1.0 \mathrm{~Hz}, \mathrm{H}-9), 7.55\left(\mathrm{~d}, 2 \mathrm{H}, J 8.7 \mathrm{~Hz}, \mathrm{H}-2^{\prime}, \mathrm{H}-6^{\prime}\right), 7.78(\mathrm{dd}, 1 \mathrm{H}, J$ 8.0, $0.7 \mathrm{~Hz}, \mathrm{H}-8), 8.16(\mathrm{~d}, 1 \mathrm{H}, J$ $8.7 \mathrm{~Hz}, \mathrm{H}-7), 8.33$ (d, $1 \mathrm{H}, J 8.5 \mathrm{~Hz}, \mathrm{H}-10), 8.52(\mathrm{~s}, 1 \mathrm{H}, \mathrm{H}-5):{ }^{13} \mathrm{C} \mathrm{NMR}\left(63 \mathrm{MHz}, \mathrm{CDCl}_{3}\right): \delta 20.10,55.42,114.69$ (2C), 118.00, 123.40, 124.77, 124.87, 125.90, 128.05, 128.41, 129.69, 130.43, 130.60 (2C), 132.27, 150.46, 155.71, 157.16, 160.64; HRMS (ESI): $\mathrm{m} / \mathrm{z}$ calcd. for $\left[\mathrm{C}_{20} \mathrm{H}_{16} \mathrm{~N}_{3} \mathrm{O}_{3}\right][\mathrm{M}+\mathrm{H}]^{+} 346.1186$, found 346.1185.

4-Methyl-6-nitro-1-(4-nitrophenyl)benzo[f]phthalazine (7d). Crystallised from propan-2-ol as yellow microcrystals $0.20 \mathrm{~g}$ (96\% yield); m.p. $260{ }^{\circ} \mathrm{C}$ (dec); $\mathrm{R}_{f} 0.17$ (50\% EtOAc/hexane); IR (KBr): $v_{\max } 1598,1528$, 1504, $1356 \mathrm{~cm}^{-1} ;{ }^{1} \mathrm{H}$ NMR $\left(250 \mathrm{MHz}, \mathrm{CDCl}_{3}\right): \delta 3.22$ (s, 3H, $\mathrm{CH}_{3}$ ), 7.50 (ddd, $1 \mathrm{H}, J$, 8.5, 7.2, $1.2 \mathrm{~Hz}, \mathrm{H}-9$ ), 7.81-7.89 (m, 3H, H-8, H-2', H-6'), 7.94 (d, $1 \mathrm{H}, J 8.7 \mathrm{~Hz}, \mathrm{H}-7), 8.36-8.46\left(\mathrm{~m}, 3 \mathrm{H}, \mathrm{H}-10, \mathrm{H}-3^{\prime}, \mathrm{H}-5^{\prime}\right), 8.57(\mathrm{~s}, 1 \mathrm{H}, \mathrm{H}-5) ;{ }^{13} \mathrm{C}$ 
NMR $\left(63 \mathrm{MHz}, \mathrm{CDCl}_{3}\right): \delta 20.20,117.93,123.97,124.47(2 \mathrm{C}), 124.69,124.87,126.08,128.18,128.58,128.68$, 130.38 (2C), 130.99, 146.21, 148.43, 150.81, 155.53, 156.99; HRMS (ESI): [ $\left.\mathrm{C}_{19} \mathrm{H}_{13} \mathrm{~N}_{4} \mathrm{O}_{4}\right][\mathrm{M}+\mathrm{H}]^{+}$requires $\mathrm{m} / \mathrm{z}$ 361.0931 , found 361.0931.

\section{Acknowledgements}

We appreciate the use of NMR and mass spectrometry facilities funded by the Network of Research Supporting Laboratories of the University of Ioannina and thank Dr. K. Tsiafoulis, and, Dr. P. Stathopoulos and Dr. A. Karkabounas, for NMR, and, low and high resolution mass spectra, respectively. We also thank Mrs. Eleni Siapi of the National Hellenic Research Foundation for the HRMS spectra of compounds $\mathbf{3 a}$, $\mathbf{4 d}$ and $\mathbf{5 b}$ - $\mathbf{d}$. This work was partially financially supported by the Ministry of Education and Science of the Russian Federation (Agreement no. 02.a03.0008).

\section{Supplementary Material}

${ }^{1} \mathrm{H}$ NMR, ${ }^{13} \mathrm{C}$ NMR and HRMS spectra are provided for all compounds. X-ray crystal data are given for compounds 5a and 6. CCDC 1519801-1519802 contain the supplementary crystallographic data for this paper. These data can be obtained free of charge from The Cambridge Crystallographic Data Centre via $\underline{\text { www.ccdc.cam.ac.uk/structures }}$

\section{References}

1. Sridharan, V.; J. Carlos Menéndez, J. C. Chem. Rev. 2010, 110, 3805-3849.

https://doi.org/10.1021/cr100004p

2. Dhakshinamoorthy, A. Synlett 2005, 3014-3015.

https://doi.org/10.1055/s-2005-921893

3. Sadek, K. U.; Al-Qalaf, F.; Mekheimer, R. A.; Elnagdi, M. H. Arabian J. Chem. 2012, 5, 63-66.

https://doi.org/10.1016/j.arabjc.2010.07.024

4. Devery, J. J.; Mohanta, P. K.; Casey, B. M.; Flowers, R. A. Synlett 2009, 1490-1494.

5. Al-Qalaf, F.; Mekheimer, R. A.; Sadek, K. U. Molecules 2008, 13, 2908-2914.

https://doi.org/10.3390/molecules13112908

6. Tale, R. H. Org. Lett. 2002, 4, 1641-1642.

7. Itoh, K.; Horiuchi, C. A. Tetrahedron 2004, 60, 1671-1681.

8. Aghapoor, K.; Heravi, M. M.; Nooshabadi, M. A.; Ghassemzadeh, M. Monatsh. Chem. 2002, 133, 107110.

https://doi.org/10.1007/s007060270012

9. Kotali, A.; Glaveri, U.; Pavlidou, E.; Tsoungas, P. G. Synthesis 1990, 1172-1173.

10. Kotali, A.; Tsoungas, P. G. Tetrahedron Lett. 1987, 28, 4321-4322.

11. Katritzky, A. R.; Harris, P. A. Kotali, A. J. Org. Chem. 1991, 56, 5049-5051.

12. Kotali, A. Arkivoc 2009, (i), 81-96.

13. Kumar, S.; Kumar, D. Synth. Commun. 2008, 38, 3683-3699.

14. Xian, H.; Qing, Z.; Jizheng. Z. Synth. Commun. 2001, 31, 2413-2418. https://doi.org/10.1081/SCC-100105117

15. Sharma, S.; Kim, A.; Park, I.; Kim, M.; Kwak, J. H.; Jung, Y. H.; Park, J. S.; Kim, I. S. Org. Biomol. Chem. 2013, 11, 7869-7876.

https://doi.org/10.1039/c3ob41644e

16. Chan, C.-W.; Zhou, Z.; Chan, A. S. C.; Yu, W.-Y. Org. Lett. 2010, 12, 3926-3929. 
https://doi.org/10.1021/ol101618u

17. Metlesies, W.; Anton, T.; Chaykovsky, M.; Toome, V. J. Org. Chem. 1968, 33, 2874-2877.

18. Newman, M.S. J. Org. Chem. 1961, 26, 2630-2633.

19. Weygand, F.; Weber, H.; Maekawa, E.; Eberhardt, G. Chem. Ber. 1956, 89, 1994-1999. https://doi.org/10.1002/cber.19560890830

20. Riemschneider, R.; Kaahn, H. G.; Hörner, L. Monatsh. Chem. 1960, 91, 1034-1042. https://doi.org/10.1007/BF00899827

21. Piggott, M. J. Tetrahedron 2005, 61, 9929-9954.

https://doi.org/10.1016/j.tet.2005.07.011

22. Vila, N.; Besada, P.; Costas, T.; Costas-Lago, M. C.; Terán, C. Eur. J. Med. Chem. 2015, 97, 462-482. https://doi.org/10.1016/i.ejmech.2014.11.043

23. Asif, M. Int. J. Pharm. Chem. 2015, 5, 398-409.

24. Haider, N.; Holzer, W. Phthalazines, In Science of Synthesis, Vol. 16; Yamamoto, Y., Ed.; Georg Thieme: Stuttgart, 2014, 315-372.

25. Robev, S. K. Tetrahedron Lett. 1981, 22, 5067-5070.

26. Perkampus, H.-H.; Bluhm, T. Tetrahedron 1972, 28, 2099-2110. https://doi.org/10.1016/0040-4020(72)88017-7

27. Hoferichter, R; Reimers, U.; Seitz, G. Arch. Pharm. (Weinheim) 1993, 326, 29-32.

28. Boger, D. L. Chem. Rev. 1986, 86. 781-793.

29. Seitz, G.; Hoferichter, R. Arch. Pharm. (Weinheim) 1988, 321, 889-890.

30. Rodgers, J. D.; Robinson, D. J.; Arvanitis, A. G.; Maduskuie Jr., T. P.; Shepard, S.; Storace, L.; Wang, H.; Rafalski, M.; Jalluri, R. K.; Combs, A. P.; Crawley, M. L. WO 05/105814, 2005; Chem. Abstr. 2005, 143, 460175.

31. Monsieurs, K.; Tapolcsanyi, P.; Loones, K. T. J.; Neumajer, G.; De Ridder, J. A. D.; Goubitz, K.; Lemiere, G. L. F.; Dommisse, R. A.; Matyus, P.; Maes, B. U. W. Tetrahedron 2007, 63, 3870-3881.

32. Chan, C. M. Synth. Commun. 1989, 19, 1981-1985. https://doi.org/10.1080/00397918908052590

33. Brown, R. F. C.; Coulston, K. J.; Eastwood, F. W.; Saminathan, S. Aust. J. Chem. 1987, 40, 107-120. https://doi.org/10.1071/CH9870107

34. Chalyk, B. A.; Kandaurova, I. Y.; Hrebeniuk, K. V.; Manoilenko, O. V.; Kulik, I. B.; Iminov, R. T.; Kubyshkin, V.; Tverdokhlebov, A. V.; Ablialimov, O. K.; Mykhailiuk, P. K. RSC Adv. 2016, 6, 25713-25723. https://doi.org/10.1039/C6RA02365G

35. Shastri, R. A. Chem. Sci. Trans. 2016, 5, 8-20.

36. Galenko, A. V.; Khlebnikov, A. F.; Novikov, M. S.; Pakalnis, V.V.; Rostovskii, N. V. Russ. Chem. Rev. 2015, 84, 335-377.

https://doi.org/10.1070/RCR4503

37. Kumar, V.; Kaur, K. J. Fluor. Chem. 2015, 180, 55-97.

38. Vitale, P.; Scilimatia, A. Synthesis 2013, 45, 2940-2948.

39. Hameed, S.; Akhtar, T. Curr. Org. Chem. 2011, 15, 694-711.

40. Giomi, D.; Cordero, F. M.; Machetti, F. Isoxazoles, In Comprehensive Heterocyclic Chemistry III, Vol. 4; Katritzky, A. R.; Rees, C. W.; Ramsden, C. A.; Scriven, E. F. V.; Taylor, R. J. K., Eds., Elsevier: Oxford; 2008, pp 365-485.

41. Belskaya, N. P.; Dehaen, W.; Bakulev, V. A. Arkivoc 2010, (i), 275-332.

42. Elassar, A.-Z.A.; Dib, H. H.; Al-Awadi, N. A.; Elnagdi, M. H. Arkivoc 2007, (ii), 272-315.

43. Himmel, D. M.; Sarafianos, S. G., Dharmasena, S.; Hossain, M. M.; McCoy-Simandle, K.; Ilina, T.; Clark, Jr. A. D.; Knight, J. L.; Julias, J. G.; Clark, P. K.; Krogh-Jespersen, K.; Levy, R. M.; Hughes, S. H.; Parniak, M. A.; Arnold, E. ACS Chem. Biol. 2006, 1, 702-712. 
https://doi.org/10.1021/cb600303y

44. Li, R.; Chen, X.; Gong, B.; Selzer, P. M.; Li, S.; Davidson, E.; Kurzban, G.; Miller, R. E.; Nuzum, E.; McKerrow, J. H.; Fletterick, R. J.; Gilmor, S. A.; Craik, C. S.; Kuntz, I. D.; Cohen, F. E.; Kenyon, G. L. Bioorg. Med. Chem. 1996, 4, 1421-1427.

https://doi.org/10.1016/0968-0896(96)00136-8

45. Kanchanadevi, A.; Ramesh, R.; Bhuvanesh, N. J. Organomet. Chem. 2015, 788, 49-57.

46. Reddy, V. K.; Reddy, S. M.; Chennaiah, A.; Reddy, P. R.; Reddy, T. S. J. Anal. Chem. (Russia) 2003, 58, 442446.

https://doi.org/10.1016/j.jorganchem.2015.04.032

47. Walcourt, A.; Loyevsky, M.; Lovejoy, D. B.; Gordeuk, V. R.; Richardson, D. R. Int. J. Biochem. Cell Biol. 2004, 36, 401-407.

48. Yang, X.; Xi, C.; Jiang, Y. Tetrahedron Lett. 2005, 46, 8781-8783. https://doi.org/10.1016/S1357-2725(03)00248-6

49. Dabiri, M.; Salehi, P.; Baghbanzadeh, M.; Bahramnejad, M. Tetrahedron Lett. 2006, 47, 6983-6986. https://doi.org/10.1016/j.tetlet.2006.07.127

50. Pairas, G. N.; Tsoungas, P. G. ChemistrySelect 2016, 1, 4520-4532.

https://doi.org/10.1002/slct.201600770 